\title{
Chapter 4 \\ Academic Misconduct in Higher Education: Beyond Student Cheating
}

\author{
Julia Christensen Hughes (1) and Sarah Elaine Eaton $(\mathbb{B})$
}

\begin{abstract}
When people hear the term "academic misconduct", student cheating often comes to mind. In this chapter we provide a broader perspective, presenting formal definitions of the terms academic integrity and academic misconduct, arguing that such concepts should apply to all members of the academy. Unfortunately, research conducted in the UK and the US suggests that faculty and administrators engage in misconduct and unethical practice, in research as well as other domains. Here we review policy changes in Canada's approach to dealing with research misconduct, with the aim of strengthening "Canada's research integrity system" (HAL in Innov Policy Econ, 2009, i). We also present public accounts of academic transgressions by Canadian faculty and administrators, with a primary focus on research misconduct. A query of Retraction Watch found 321 retractions involving academics working in Canadian higher education institutions during the years 20102020. Articles in the press are then used to further highlight incidents of academic fraud and plagiarism, as well as questionable practices in student supervision, hiring practices, international student recruitment, and inappropriate interpersonal relationships. We conclude by calling for a comprehensive study of academic misconduct by faculty and administrators at Canadian higher education institutions as well as an assessment of how well the changes to Canada's policies on research misconduct are working, particularly with respect to public disclosure.
\end{abstract}

Keywords Faculty $\cdot$ Administrators $\cdot$ Academic Misconduct $\cdot$ Research

Misconduct

\footnotetext{
J. Christensen Hughes ( $\square$ )

Yorkville University, Toronto, Canada

e-mail: jchristensen@yorkvilleu.ca

\author{
S. E. Eaton $(\varangle)$ \\ University of Calgary, Calgary, Canada \\ e-mail: seaton@ucalgary.ca
}




\section{Introduction}

The term "academic misconduct" is often narrowly used in reference to various types of student violations of academic integrity such as plagiarism or exam cheating. In this chapter, we challenge this notion by providing a broader perspective. We begin with a discussion of the formal definitions of the terms academic integrity and academic misconduct, arguing that such concepts must apply to all members of the academy, and in particular, the behaviour of faculty and administrators who serve as important role models and set the moral tone. Unfortunately, and despite the essentiality of integrity to the academic mission, research suggests that some administrators and faculty do engage in misconduct, including in their scholarly pursuits, as well as administrative practices.

Next, we review calls made between 2007 and 2011 to strengthen "Canada's research integrity system" (HAL, 2009, i), as well as the policy changes that followed. Building on the work of Eaton (2020a, b; 2021), we then present examples of research misconduct as well as other transgressions by faculty and administrators, highlighting common themes. In particular, we present the results of a query to a data base maintained by Retraction Watch, which found 321 retractions involving academics working at Canadian higher education institutions between 2010-2020, as well as stories of misconduct in the Canadian media. We conclude by calling for a comprehensive study of academic misconduct by faculty and administrators at Canadian higher education institutions as well as an assessment of how well the changes to Canada's policies on research misconduct are working, particularly with respect to public disclosure.

\section{Defining Academic Integrity and Academic Misconduct}

In the Handbook of Academic Integrity, editor Tracey Bretag (2016) observed, "[a]cademic integrity is such a multifarious topic that authors around the globe report differing historical developments which have led to a variety of interpretations of it as a concept and a broad range of approaches to promulgating it in their own environments" (p. 3).

In 1999, the International Center for Academic Integrity (ICAI) advanced what has arguably become the most common definition of academic integrity in use in Canada today: "A commitment, even in the face of adversity, to five fundamental values: honesty, trust, fairness, respect and responsibility" (ICAI, 2021). A sixth value — "courage"- - was added later, in recognition that doing the right thing, in the face of adversity, can require considerable personal courage.

Similar to many of the concepts embedded in this multi-faceted definition, the Merriam Webster (n.d. a) on-line dictionary, defines integrity as, "firm adherence to a code of especially moral or artistic values: incorruptibility. 2: an unimpaired condition: soundness. 3: the quality or state of being complete or undivided: completeness." 
Its synonyms include, "character, decency, goodness, honesty, morality, probity, rectitude, righteousness, rightness, uprightness, virtue, virtuousness" (Merriam Webster n.d. a).

In contrast, misconduct - often mistakenly treated as an antonym to integrityis defined much more narrowly. Merriam Webster (n.d. b) defines misconduct as, "1: mismanagement especially of governmental or military responsibilities. 2: intentional wrongdoing specifically: deliberate violation of a law or standard especially by a government official: MALFEASANCE. 3a: improper behavior...". Its synonyms include, "malfeasance, misbehavior, misdoing, wrongdoing" (Merriam Webster, n.d. b).

Applying these concepts to higher education in Canada, and writing in University Affairs, Mullens (2000, p. 23), lamented that "maintain[ing] a culture of academic integrity is now a considerable worry on campuses across Canada". Narrowly focusing on the behaviour of students, she defined academic dishonesty as, "anything that gives a student an unearned advantage over another."

Many Canadian institutions have drawn on one or more of these concepts in advancing their own definitions. As one example, Ryerson University's Senate documents draw explicitly from the ICAI's definition, applying academic integrity to all members of the university, yet define academic misconduct as a student-focused concern:

This policy is premised on the commitment of the University to foster and uphold the highest standards of academic integrity, the fundamental values of which are honesty, trust, fairness, respect, responsibility, courage ...All members of the University community, including faculty, students, graduate assistants (GAs), and staff, have a responsibility to adhere to and uphold [these values] in their teaching, learning, evaluation, research, and creative activity. This includes a responsibility to take action if they have reasonable grounds for thinking that academic misconduct has occurred.

Academic Misconduct is any behaviour that undermines the university's ability to evaluate fairly students' academic achievements, or any behaviour that a student knew, or reasonably ought to have known, could gain them or others unearned academic advantage or benefit, counts as academic misconduct. (Policy 60, Ryerson, n.d.)

In its definition of academic integrity, the University of Waterloo similarly draws on the ICAI's definition, emphasizes that it applies to everyone, and explains why integrity in the awarding of degrees is important:

Whether learning, teaching, researching or working, members of our community must conduct themselves honestly. Acting with integrity reinforces the university's reputation as a leading teaching and research institution.

As a post-secondary institution, the value of the degrees the university awards deserving students at the end of their studies is dependent on the legitimacy of the education these students earn. A degree is valueless without integrity... . (University of Waterloo, n.d.)

Waterloo also cites the teachings of the Seven Grandfathers in Academic Integrity (Maracle, 2020), first adopted by the University of Toronto, which include: Respect, Bravery, Honesty, Wisdom, Humility, Truth, and Love.

Individual faculties and departments within Canada's higher education institutions have embraced similar approaches. As one example, the Faculty of Health 
Sciences and Wellness at Humber College also draws on the ICAI's definition while encouraging students to take an academic integrity pledge; "Each year, approximately 1,500 students pledge to study with the values of honesty, trust, fairness, respect, and responsibility with courage even when faced with adversity" (Humber College, n.d.).

Academic associations in Canada have also advanced definitions and stated their commitment to upholding integrity. Universities Canada's statement on academic freedom, for example, includes the declaration that, "central to the mandate of Canadian universities has long been the pursuit of truth, the education of students and the dissemination of knowledge" (Dea, 2019). According to Dea, faculty are expected to uphold certain tenants while engaging in these pursuits, including:

[C]onducting scholarship honestly, ethically, and according to the standards of your discipline or subdiscipline. That means performing your assigned teaching duties, grading student work fairly, subjecting one's work to peer review, reporting research results honestly, properly crediting other scholars' contributions, being careful not to misrepresent one's own expertise or position (for instance, being clear that one's extramural expression does not represent one's university), and so on. (Dea, 2019)

Colleges and Institutes Canada, which represents Canada's colleges, institutes, cegeps and polytechnics, recently produced a strategic plan (2019-2024), that similarly (but less specifically) acknowledges the organization's commitment to upholding "the principles of agility, inspiring others, and integrity in all that we do" (Colleges and Institutes Canada, 2021).

Upholding such values could not be more essential to the success of higher education institutions, whether conferring students with degrees, disseminating research findings in service to society, administering policies and practices, or providing strategic leadership, shaping institutional priorities and cultures. Indeed, higher education institutions have long been "perceived as epitomizing intellectual and social honesty, and they are expected to strive continually for that form of perfection" (Besvinick, 1983, p. 569). Yet evidence suggests - as presented in the next section and elsewhere-higher education has long fallen short of this promise (see for example Christensen Hughes 2022). We begin the next section with a brief review of faculty and administrator misconduct in the academy, in Britain, the US and elsewhere.

\section{Misconduct in the Academy}

Ten years ago Stone and Starkey (2011), provided a damning report on "doubtful ethics" in the British academy. Reflecting on their personal experience as instructors, and following a comprehensive literature review, the authors suggested that as a result of myriad factors, including economic pressures and government imposed performance metrics, many higher education institutions had become "self-serving, marketised, institutions, where students who pay increasingly high fees are subject to increasingly poor teaching and declining quality standards" (p. 156). They observed that the top priorities of higher education had become "money and research, while 
students come a poor third...Universities beckon students to come and learn, but are actually institutions primarily for maximising career opportunities for their staff, who teach decreasing hours and vie for promotion" (p. 158).

Corrupt, unethical and questionable practices they found evidence of pertained to a variety of domains, including (Stone \& Starkey, 2011, 159-60):

- journal practices (poor quality refereeing, insider clubs, inappropriate creditforced addition of senior names and suppression of junior names).

- access (favouring "well-connected" applicants and athletes; administrators taking bribes; students faking qualifications);

- falsified grades and degrees (bought through diploma mills, bribes, sexual favours);

- foreign student fees (attracting large numbers of unqualified students for tuition revenue);

- plagiarism and cheating (contract cheating, faculty not enforcing codes of conduct);

- quality issues (poor teaching, unclear/inappropriate assessment criteria, overly generous in marking to increase retention and student satisfaction scores, failure to update teaching material);

- faculty research (skimming funds, commercial funding influence, falsification of results, plagiarism); and,

- falsification of faculty records (falsification of CVs, representing faculty as employed and contributing to university when they are not, in order to drive rankings)

Ospian (2004, 2007) similarly explored corruption in higher education, which he concluded was related to issues of access, quality and equity $(2007$, p. 2). The examples he identified, based on his review of articles in the press in the US, UK and Russia, included "bribery, fraud, cheating, plagiarism, diploma mills, breach of contract and other forms of misconduct" as well as "credentials fraud and research fraud" (2007, p. 35).

Highlighting the difficulty of assessing the extent to which faculty research misconduct may be occurring, Smith (2006) observed:

Most cases are probably not publicized. They are simply not recognized, covered up altogether, or the guilty researcher is urged to retrain, move to another institution or retire from research. (Smith, 2006, p. 4)

Further, Smith (2006) suggested that while some researchers are found guilty, fired and/or professionally disgraced, supervisors have treated such cases as "isolated incident[s]", and have been "slow to respond" (p. 1).

So concerning has research misconduct become, that explanations for its occurrence-in peer reviewed papers and faculty blogs alike-have shifted from the personal ("bad apples") to the systemic ("bad barrels" and "bad systems"), such as publication pressures and competition for research funding (Huistra \& Paul, 2021, p. 2). Gervais (2021), for example, described a "toxic scientific ecosystem" in psychology (p. 15), evidenced by a "flurry of unsuccessful replications of prominent 
work, exposure of scientific fraud and negligence bordering on fraud, and publication of highly implausible research" (p. 1).

Another study investigated the practices of academic journal editors (Hamilton et al., 2020, p. 1). Despite its centrality to academic quality, they found wide variation in peer review processes, including that the majority allowed authors to recommend reviewers. Only half (49\%) routinely checked for plagiarism.

Faculty are bemoaning the lack of standards and emerging pressures that are further eroding publishing system. Jones (2021) observed, "we are heading rather rapidly into a blizzard of material with no vetting or meaningful review" (para. 2). Specific concerns identified by Jones (2021) included: "open access upon publication"; "high levels of publication for tenure, promotion and funding"; "preprint servers"; "junk journals"; "reviewer fatigue"; and, "expansion of research into more of academia" (para. 3).

In keeping with these findings and perspectives, Smith (2006) observed, "All human activity is associated with misconduct. Indeed, misconduct may be easier for scientists because the system operates on trust" (p. 4). Further, junior researchers are often the whistleblowers, who can "encounter more problems than those on whom they blow the whistle-even when they are thoroughly vindicated" (p. 5). Recommendations from Smith (2006) included modernizing the accountability of journal editors, and creating "a national body to provide leadership" (p. 4).

\section{Faculty and Administrator Misconduct in Canada}

A comprehensive study has not yet been undertaken on misconduct by faculty and administrators at Canadian higher educational institutions. The types of behaviours, systemic pressures and potential solutions identified above, could provide a useful framework for such an undertaking. For now, in this section and building on the work of Eaton (2020a, b; 2021), we share examples of alleged academic misconduct by Canadian faculty and senior administrators available via Retraction Watch (n.d. a) and as reported in the Canadian press. While we have chosen to largely focus on research misconduct, other transgressions, such as those involving plagiarized speeches, questionable admissions practices, and inappropriate interpersonal relationships are also briefly highlighted.

Seemingly not as plentiful as media accounts of student cheating (see Christensen Hughes \& Eaton, 2022), or misconduct by faculty and administrators in other countries (as reviewed above), we wondered if Canadian institutions are better at covering up transgressions (dealing with such issues confidentially as private, personnel matters), or if such incidents are in fact less prevalent than elsewhere. Regardless, cases of research misconduct by those working at Canada's higher education institutions became sufficiently concerning, that between 2007 and 2011 a concerted effort was made to review and strengthen the country's research integrity policies. We begin the next section by providing examples of the types of incidents 
that prompted this national response, as well as some of the key observations and recommendations that followed.

\section{Efforts to Strengthen Canada's Integrity System}

One of the most well-known Canadian cases of research misconduct involved R. K. Chandra, a faculty member at Memorial University, who was suspected of fabricating or falsifying data across multiple publications (Smith, 2006). While the university reportedly investigated and found no problem, Chandra ultimately left, moving to Switzerland. In 2005 the CBC produced a three part investigative series on Chandra, called The Secret Life of Dr. Chandra (CBC News, 2005), claiming that he had hundreds of bank accounts and suggesting that Chandra may have engaged in a number of fraudulent financial activities over many years.

Another high profile Canadian case involved Eric Poehlman, who was hired by the University of Montreal and awarded a Canada Research Chair, while being under investigation for numerous research violations in the US (Dalton, 2005). After resigning his faculty position, Poehlman "acknowledged falsifying 17 grant applications to the National Institutes of Health (NIH) for nearly \$3 million, and fabricating data in ten published articles" (Dalton, 2005, para. 2).

Suggesting that other academics have quietly moved along once suspicions have been raised, Daniel Kwok, an engineering professor and Canada Research Chair at the University of Alberta was being investigated for misconduct, including inappropriately using research funds for personal benefit (purchasing car parts and entertainment systems) before he moved to the University of Calgary. Once there, he came under additional scrutiny and was eventually banned from future funding by Canada's National Sciences and Engineering Research Council (NSERC). Kwok was accused of plagiarism and the fraudulent use of research funds, also over many years (Hoag, 2010; Jerema, 2010; Munro, 2010).

Highlighting problems arising from the undue influence of industry partners, Barbara Sherwin, a psychology professor at McGill, is alleged to have been "part of a ghostwriting scheme paid for by drug giant Wyeth Pharmaceuticals to promote its products" (Laidlaw, 2009). Her compromised paper, published in the Journal of the American Geriatrics Society, suggested that estrogen could be effective for treating memory loss, cardiovascular disease, osteoporosis, and colorectal cancer.

Growing concern over cases such as these prompted the Canadian Research Integrity Committee (CRIC) to host a workshop on Research Integrity: Towards a Canadian Approach in 2007. Those involved included representatives from "16 Canadian research and academic institutions", the Association of Faculties of Medicine of Canada", and Canada's three national granting councils: the Canadian Institute of Health Research (CIHR), the Natural Sciences and Engineering Research Council of Canada (NSERC) and the Social Sciences and Humanities Research Council (SSHRC) (HAL, 2009, p. 1). The workshop resulted in the CRIC commissioning a study to review research integrity in Canada. 
Consulting firm Hickling, Arthurs, Low (HAL), undertook the project, producing The State of Research Integrity and Misconduct Policies in Canada (HAL, 2009). The report's stated purpose was to "develop a comprehensive understanding of the organizations and policies that define how allegations of research misconduct are addressed in Canada and in other selected countries" and to "inform a discussion... about how best to strengthen Canada's research integrity system" (HAL, 2009, p. i).

The HAL (2009) report highlighted the damaging consequences of fraudulent research such as wasted resources (time, effort and money) as well as "potential harm to individuals and society" (p. i) including "unsafe products" and eroding "the public's trust in science" (p. ii). It also noted the importance of Canada's Tricouncil Policy Statement on Integrity in Research and Scholarship (TCPS-IRS). In Canada, higher education institutions are responsible for responding to allegations of misconduct, in keeping with "the framework of the TCPS-IRS, and other institutional, international and, or, provincial policies" (p. ii).

Shortcomings of Canada's approach were found to be numerous, including: "a weakness in formal oversight; inadequate reporting requirements; inconsistent educational efforts; differing definitions as to what constitutes research misconduct; and poor whistleblower assistance" (HAL, 2009, p. iv). In terms of prevalence, the 29 institutions that participated in the study reported "dealing with some 39 cases per year" (p. iv). The report also acknowledged that these numbers likely understated the extent of the problem, given myriad factors including a tendency to sweep such issues "under the carpet" (p. iv).

While acknowledging variation in institution-specific definitions and policies, and the importance of exercising discretion in cases "based on misunderstanding or due to poor oversight" (HAL, 2009, p. iii), the HAL report underscored that "more needs to be done in Canada to address research integrity" (p. 4). This conclusion echoed a question raised in the Canadian Medical Association Journal; "Why has Canada lagged so far behind its Western counterparts in establishing comprehensive mechanisms and processes to deal with scientific misconduct?" (Kondro \& Hebert, 2007).

Recommendations included the adoption of "an explicit national definition of research misconduct that identifies sanctionable behaviors in addition to the current definition of research integrity" (HAL, 2009, p. iii). They also recommended, "strengthened reporting requirements that necessitate the public reporting on an annual basis of all cases where research misconduct is found" (p. v). Other possible actions included the establishment of a "national system that gives well-meaning individuals with concern a place to go for information and assistance that is independent from their employer" (p. iv), such as an "Office of an Ombudsperson" or a "Canadian Office of Research Integrity" (p. vi).

Shortly after, a related study was undertaken at the request of Tony Clement, then Canada's Minister of Industry. An expert panel, under the auspices of the Council of Canadian Academies (CCA), and chaired by Paul Davenport, former president of Western University, produced a second report, Honesty, Accountability and Trust: Fostering Research Integrity in Canada (CCA, 2010). Amongst this report's recommendations was that "Canada must address the gaps in the existing research system 
that are undermining the system's transparency and accountability" (CCA, 2010, p. 2). Highlighting the panel's support for disclosing the names of "researchers and institutions convicted of breaching research integrity policy and the details of any imposed sanctions", Paul Davenport acknowledged, "There is a tension between society's desire to know quickly about allegations and to have strong privacy law" (Hoag, 2010).

Other recommendations included, "Canada needs a common, system-wide approach to research integrity that involves all actors"; "There is a need to foster a positive, values-based environment of research integrity in Canada", and "Canada needs a new entity, the Canadian Council for Research Integrity [CCRI], to serve as a central educational and advisory arm on issues of research integrity" (CCA, 2010, p. 2).

There were at least three significant outcomes from these undertakings. The first was the launch in 2011 of the Advisory Panel on Responsible Conduct of Research (PRCR). The PRCR's mandate is to:

consider allegations of breaches of Tri-Agency policies by reviewing institutional investigation reports; recommend recourse, if appropriate, consistent with the Framework; provide advice to the Agencies on matters related to the responsible conduct of research; provide advice to the Agencies on revisions to the Framework; and review the Framework every five years. (PRCR, 2016)

The second, was that beginning November, 2011, under the auspices of the PRCR, researchers seeking funding from Canada's granting agencies were required to consent to having their names officially released, should a serious breach of research integrity be found to have occurred (Consent to Disclosure of Personal Information-Frequently Asked Questions, 2016):

The Agencies may also publicly disclose information related to a serious breach without consent, if "in the opinion of the head of the institution, the public interest in disclosure clearly outweighs any invasion of privacy that could result from the disclosure" (Privacy Act, 8(2) (m) (i)). (PRCR, 2017)

The third was the publication of the Tri-Agency Framework:Responsible Conduct of Research, referred to in the PRCR mandate, which was updated in 2016 (see RCR Framework, 2016). In the spring of 2021, the PRCR undertook a second revision of the Framework, through a process of public consultation. Proposed revisions pertained to clarifying certain definitions such as "lack of rigour", "falsification", and "destruction of research records". Other revisions sought to clarify and expand the responsibilities of researchers and institutions, such as providing "adequate oversight of, and training to, their trainees and staff in responsible conduct of research", and being "proactive in supporting a healthy research environment". Other items pertained to process, including "guidance on what institutions should consider disclosing at the end of an RCR process" (RCR Framework (2016) - Proposed Revisions for Public Consultation, 2021). This last item was likely the most contentious of the recommendations.

Despite the existence of disclosure policy, it is noteworthy that only one case to date-that of Sophie Jamal-has been officially released (Oransky, 2016). In this 
particular case, the CIHR permanently banned Jamal from further funding. Jamal resigned from Women's College Hospital (WCH) and the University of Toronto, following an investigation in which she was found to have:

\begin{abstract}
Manipulated study data with the intention of supporting the underlying hypothesis of research studies; intentionally manipulated electronic datasets and presented them as raw data to investigators; falsely accused a research assistant of having carried out the manipulations; failed to correct the errors once the problems were discovered; shared manipulated rather than primary data with colleagues; deleted records that were to form part of WCH's forensic investigation; failed to retain research data to a standard appropriate to the discipline; and impeded an institutional investigation. (Oransky, 2016)
\end{abstract}

Responding to Canada's long standing practice of keeping such incidents private, James Turk, executive director of the Canadian Association of University Teachers, observed, "If someone is convicted of research misconduct, that should be known... if there is a finding of research misconduct then I think it should be made public" (Munro, 2011). The proposed 2021 revisions, do not make public disclosure any more likely, with its stated clarification that "Recourse against a Respondent should only be shared with the Respondent" (RCR Framework (2016) - Proposed Revisions for Public Consultation, 2021).

\title{
Retraction Watch
}

One organization dedicated to helping make serious incidents of research misconduct public is Retraction Watch (n.d. a). Supported by the MacArthur Foundation, the Arnold Foundation, and the Helmsley Trust, researchers Dr. Adam Marcus and Dr. Ivan Oransky founded Retraction Watch in 2010 as result of their growing concern about misconduct in medical research, the amount of time it was taking for retractions to occur, and the ongoing citation of discredited work. They concluded that engaging the media was essential for correcting the record; "If highlighting retractions will give journalists more tools to uncover fraud and misuse of funds, we're happy to help" (Oransky \& Marcus, 2010).

Retraction Watch publishes daily accounts as well as weekly summaries of some of the most egregious practices, including fabricated data, doctored slides, and unreported conflicts of interest, particularly galling in pharmaceutical research published in medical journals. As one example, Retraction Watch is keeping a running tally of papers retracted concerning Covid-19. By April 2021, over 100 were on the list, with several other papers receiving "expressions of concern" (Retraction Watch, n.d. b).

In addition to highlighting recent publications, Retraction Watch also tracks papers published decades earlier that have been recently challenged on the basis of changing societal norms and evolving understandings of "bad" science. As one example, Retraction Watch (2020a) reported on the retraction of a paper on homosexuality and conversion therapy, published in 1951 in the Journal of Nervous and Mental Disease. Current journal editor John Talbott observed how social norms impact scientific findings: 
The 1951 Glover article supports long discredited beliefs, prejudices, and practices (conversion therapy) and will be retracted as requested. It will, however, be kept in the journal's archives for its historical value... But journals like this one, published papers in the past reflecting many other beliefs we find abhorrent today, such as those on eugenics, the disabled, women, Blacks, sexual problems, and yes, sexuality. (Retraction Watch, 2020a)

Highlighting the social harm such research can effect, Retraction Watch observed that the paper, “offered a medical rationale for President Eisenhower's 1953 declaration that homosexuals represented a threat to national security and were therefore to be removed or banned from federal employment" (Retraction Watch, 2020a). In Canada, work by J. Philippe Rushton (now deceased) on racial differences has similarly been retracted. Formerly on faculty at Western University, Rushton's work has been deemed "unethical, scientifically flawed, and based on racist ideas and agenda" (Retraction Watch, 2020b).

Retraction Watch also reports on stories on mass retractions, such as when Springer announced it was retracting over 100 papers on cancer research from one journal, Tumor Biology, now published by Sage, due to fraudulent reviews. In this case, false email accounts were allegedly used to misdirect papers to fake/favourable reviewers (Retraction Watch, 2017).

Most importantly for this chapter, Retraction Watch maintains a searchable database (by country, university etc.) of retracted papers (Retraction Watch, n.d. c). In fall, 2020 we requested a query of retractions involving academics with a Canadian university affiliation, for the years 2010-2020. The report found 397 Canadian university affiliations, pertaining to 321 retracted articles (Note: the number of institutional affiliations are higher than the number of articles, as an article may have more than one Canadian author). Annual rates of retracted papers varied from a low of 17 in 2013 to a high of 48 in 2019. The Canadian institutions that figured most prominently (with more than 10 author affiliations each) are listed in Table 4.1. Interestingly, all belong to Canada's prestigious "U-15 Group of Canadian Research Universities". Twenty-one other Canadian institutions had between two and nine affiliations each.

There were also 786 reasons provided for the 321 retracted papers $(2.45$ per paper on average). The most common are listed in Table 4.2 (i.e., those with a minimum of 20 instances):

The most common reason for retraction was "Duplication of Articles (by journal)", meaning the article was mistakenly published more than once, as a result of journal error (Retraction Watch, n.d. d). Reasons where the authors clearly bore responsibility included: "Unreliable Results", "Error in Data", "Plagiarism of Article", "Manipulation of Images", and "Falsification/Fabrication of Data".

\section{Incidents of Misconduct Highlighted by the Canadian Press}

In addition to Retraction Watch, and as its founders envisioned, the press is another important source of information on misconduct by Canadian academics, as well as the effectiveness of national policies. In 2016, for example, the Toronto Star ran an article on research fraud in Canada, reporting that while the PRCR's Secretariat on 
Table 4.1. Canadian universities with ten or more retraction affiliations (2010-2020). (Source Retraction Watch)

Table 4.2. Most common reasons for retractions of papers by Canadian academics, 2010-2020. (Source Retraction Watch)

\begin{tabular}{l|l}
\hline Institution & $\begin{array}{l}\text { \# Times affiliation appeared } \\
\text { on retracted papers } \\
2010-2020\end{array}$ \\
\hline University of Toronto & 98 \\
\hline University of British Columbia & 33 \\
\hline University of Calgary & 26 \\
\hline McGill University & 24 \\
\hline University of Ottawa & 21 \\
\hline University of Alberta & 19 \\
\hline McMaster University & 17 \\
\hline University of Montreal & 17 \\
\hline University of Saskatchewan & 15 \\
\hline University of Western Ontario & 15 \\
\hline Dalhousie University & 11 \\
\hline University of Waterloo & 11 \\
\hline Total & 307
\end{tabular}

\begin{tabular}{l|l}
\hline Reason for retraction & Times used \\
\hline Duplication of Article (by journal) & 51 \\
\hline Investigation by Company/Institution & 50 \\
\hline Notice_Limited or No Information & 50 \\
\hline Investigation by Journal/Publisher & 32 \\
\hline Unreliable Results & 32 \\
\hline Withdrawal & 29 \\
\hline Error in Data & 28 \\
\hline Plagiarism of Article & 26 \\
\hline Manipulation of Images & 25 \\
\hline Concerns/Issues About Data & 24 \\
\hline Error in Analyses & 23 \\
\hline Date of Retraction/Other Unknown & 22 \\
\hline Duplication of Image & 22 \\
\hline Error by Journal/Publisher & 22 \\
\hline Falsification/Fabrication of Data & 22 \\
\hline
\end{tabular}

Responsible Conduct of Research was tracking and reporting on cases, Canadian researchers were still not being named:

Seventy-eight Canadian scientists have fabricated data, plagiarized, misused grants, or engaged in dodgy scientific practices in projects backed by public funds... 
But the publicly funded agency responsible for policing scientific fraud is keeping secret the details surrounding these researchers. The scientists' names, where they worked and what they did wrong is not made public because that information is protected under federal privacy laws.... (Robinson, 2016)

Robinson (2016) also explained, however, that "By law, the presidents who lead each of Canada's research funding agencies... have the power to release the findings of these investigations if it is deemed to be of significant public interest, defined as a concern of public health or national security."

One particularly egregious case involved fraudulent cancer research at the University of British Columbia (UBC), where "in 2014 investigators identified 29 instances of scholarly misconduct, 16 of them 'serious,' including falsification and fabrication of data... [The] tainted work had been included in 12 papers published in six journals between 2005 and 2012" (Komnenic, 2016). UBC did not release the results of their investigation or name the researcher, citing British Columbia's privacy laws and claiming that to do so was not "clearly" in the public interest.

Another example involved Dongqing Li, who held a prestigious Canada Research Chair at the University of Waterloo and a PhD student. Martin Bazant, a professor at the Massachusetts Institute of Technology accused Li of having plagiarized material from a "pre-published version" of an article he had submitted to the journal, Microfluidics and Nanofluidics, which Li founded and was serving as editor-in-chief (Brennan, 2012; CTV News, 2013). The article was retracted, Li resigned his editorship (Brennan, 2012) and he was also suspended from the University without pay for four months (CTV News, 2013).

One particularly notorious case involved Dr. Cory Toth, "former research director of the Calgary Chronic Pain Centre Clinic", who had received "more than \$2.3 million in research funding in his nine years at the medical school" (Munro, 2014). Toth was the corresponding author on multiple published articles found to contain manipulated data and figures:

[T]he journals Molecular Pain and Brain retracted two of Toth's team studies for data manipulation and two more studies in Diabetes were retracted for image doctoring, "fabricated" figures, and using "older data not representative of the cohorts (of mice) studied." Then this summer RETRACTED, in bold red type, was slapped on two papers in the journal Neurobiology of Disease, for data manipulation. The two most recent retractions, in the journal Neuroscience, are for "manipulated" figures and "faulty data"-bringing the total to nine. (Munro, 2014)

Commenting on the case, Dr. Ivan Oransky said, "I can't say whether it's an official record, but we haven't seen anyone else in Canada retract that many papers since we launched in 2010" (Munro, 2014).

Underscoring the particular vulnerabilities of graduate students, Shahid Azam, an engineering professor from the University of Regina, had a paper retracted after being found by the journal to not have given proper attribution to the thesis work of one of his master's students (Leo, 2014). Calling it a "grey area" and matter of "poor judgment", the journal said that Azam would not be banned from making future submissions. In his defense, the professor claimed to have written large parts of the student's thesis himself, suggesting that "in the field of engineering, it's common 
and acceptable for researchers to 'reuse' their own text from previous articles in subsequent papers". The graduate student Arjun Paul claimed "he wrote the papers and the thesis himself" (Leo, 2014). This case highlights the need to bring greater transparency to supervisor relationships and co-publishing practices.

As an example from the field of education, the University of Windsor suspended and demoted Clinton Beckford, its newly appointed dean of education after he was found to have engaged in plagiarism, following a formal investigation (CBC News, 2012; Chen, 2012). Another education leader who made the news was Chris Spence, the former director of the Toronto District School Board, who was found by the University of Toronto to have plagiarized large portions of his 1996 doctoral thesis (Alphonso, 2017). Spence resigned his position and his PhD was rescinded (Mandel, 2019).

Research misconduct — as previously suggested — is not the only type of academic integrity violation that has been in the Canadian press. One now infamous example of plagiarism in a convocation address involved Philip Baker, the former Dean of Medicine at the University of Alberta. Baker resigned after students discovered that his remarks were taken almost verbatim-including "personal stories about how medical science has helped his wife and children"-from an address previously made by “Atul Gawande, at Stanford University's 2010 medical school convocation" (CBC News, 2011). Class president Brittany Barber made a statement on behalf of students:

To realize all this hard work may be marred by this unanticipated incident is very disheartening to the students. People should know that we will not stand for this academic dishonesty, and our deepest wish is that this incident does not reflect poorly on the integrity of our class, the medical school and, ultimately, the university. (CBC News, 2011)

Prior to coming to Canada, Baker had been at the heart of a medical scandal, where he was implicated in the death of a baby in Nottingham, England. A court ruling found Dr. Baker had provided "substandard and inappropriate" care (Weaver, 2000). This previous case was not mentioned in the 2011 Canadian press reports and raises questions concerning a potential lack of due diligence in academic appointments. Eaton (2020a; 2020b; 2021) questioned whether faculty should have to declare previous incidents in which findings of misconduct (academic, professional, personal) have been made. As of 2021, Baker is serving as the Pro-Vice-Chancellor and Head of College of Life Sciences, Dean of Medicine University of Leicester, in the UK.

Highlighting questionable practices in student recruitment, Broitman (2016), Director of Higher-Edge, which operates the Canadian University Application Centre, wrote about the impact of increasing financial pressures and competition:

It is overwhelmingly evident that in the last two decades we have witnessed first-hand a remarkable and callous disregard for academic ethics and standards in a scramble by Canadian universities and colleges to sign up foreign students, who represent tens of millions of dollars to their bottom lines. (para. 3)

Specifically, Broitman (2016) called out "corrupt practices" and "contracted relationships between universities and colleges with education agents worldwide", suggesting that: 
Although Canadians typically think of their society and themselves as among the more honest and transparent found anywhere, how many Canadian institutions are engaging in activities that border on dishonest and are not entirely transparent around the world?. (Broitman, 2016, para. 2)

He also identified unsettling consequences of admitting students with poor English literacy skills, and/or those who are poorly academically prepared, such as undue pressure on faculty to ensure they pass regardless; "Some have reported failing students who later (somehow) manage to have passed. As we know, failing students is bad for business" (para. 5). Strikingly, Broitman (2016) concluded:

Too few academic institutions are serious enough about screening and vetting applications...It's not just academic integrity that is lacking, academic quality is diminishing as cohorts of international students grow in number but not in ability...

Most professors know what's going on. Yet, unless you listen carefully to low whispers on Canadian campuses you never hear of the academic compromises made in the interest of revenue... Ask any reporter how hard it is to get anyone to go on record. (Broitman, 2016, para. 10-11)

Inappropriate sexual relationships are yet another area of concern. As one example, Jim Pfaus, a psychology professor at Concordia University, retired after an internal investigation in which he was accused of inappropriate behavior with students, including that he had "pursued, dated or had sexual relationships with students in his classes or under his supervision" (Hendry, 2019). The article noted that at the time, Concordia did not have "a specific policy or guidelines discouraging professor-student romantic or sexual relationships". Following, Quebec's Ministry of Higher Education introduced Bill 151 (2017), "An Act to prevent and fight sexual violence in higher education institutions", requiring institutional policies on sexual violence. One of the outcomes, is that all new staff, faculty and students at Concordia must now complete "sexual violence awareness and prevention training" (It Takes All of Us, 2021).

\section{Declining Trust in the Academy}

Given these stories, perhaps it is not surprising that as identified as a concern in the HAL (2009) report, support for higher education and trust in academics and scientists in North America appears to be waning. In the US, a 2018 Gallup poll found a considerable decline, with less than half (48 percent) of American adults indicating they have "'a great deal' or 'quite a lot' of confidence in higher education" (Jaschik, 2018). According to Lawrence Bakow, President of Harvard University, "declining public support for higher education is one of the major challenges facing academe":

For the first time in my lifetime, people are asking whether or not colleges and universities are worthy of public support. For the first time in my lifetime, people are expressing doubts about whether colleges and universities are even good for the nation. These questions force us to ask: What does higher education really contribute to the national life? (Jaschik, 2018, para. 9) 
Another US study similarly found declining trust in scientists. Participants expressed particular concern about research misconduct (Funk, Hefferon, Kennedy \& Johnson, 2019, p. 1):

\begin{abstract}
Most Americans are skeptical about key areas of scientific integrity. No more than two-in-ten Americans believe scientists across these groups are transparent about potential conflicts of interest with industry all or most of the time... Between about a quarter and half of Americans consider misconduct a "very big" or "moderately big" problem, with the public generally skeptical that those engaged in misconduct routinely face serious consequences.
\end{abstract}

More recently, the Annual Edelman Trust Barometer (2021) reported that trust in societal institutions fell in many countries around the world between May 2020 and January 2021, including amongst Canadian respondents, with business surprisingly emerging as the only institution perceived as being both competent and ethical (p. 7). The overall trust score found that just $56 \%$ of global respondents indicated they trust their social institutions (p. 9). Canada mirrored this result, up slightly from $53 \%$ in 2020 (p. 9). In terms of academics, their credibility as spokespeople was perceived as more trustworthy than CEO's, government officials and journalists, but the extent to which they were considered "very/extremely credible" declined considerably over 2020, down 8 points to $59 \%$ (p. 22). The authors concluded:

After a year of unprecedented disaster and turbulence-the Covid-19 pandemic and economic crisis, the global outcry over systemic racism and political instability-the 2021 Edelman Trust Barometer reveals an epidemic of misinformation and widespread mistrust of societal institutions and leaders around the world. (Annual Edelman Trust Barometer, 2021, para. 1)

Within Canada, declining political trust in the academy has been reflected in increasing government oversight ("regulation and accountability measures"). One study of research-intensive Canadian universities (Eastman et al., 2018), observed that provincial governments are "seeking to align universities' activities or outcomes more closely with desired public policy goals" through enhanced "governance, transparency, accountability, value for money, and alignment with government's public policy priorities" (p. 72). While part of this distrust pertains to what students are learning, the academy is also clearly being challenged with respect to the value and impact of its research.

\title{
Recommendations and Conclusion
}

In summary, although we cannot say to what extent misconduct is occurring by faculty and administrators within Canada's higher education institutions, the aforementioned examples of research misconduct are deeply concerning. Reports of Canadian researchers fabricating and falsifying data and grant applications, doctoring images, fraudulently using research funds, failing to declare conflicts of interest, engaging with ghost writing services, and plagiarizing graduate work and in speeches, all serve to undermine public trust in science and the academy. While not the focus of this 
chapter, additional areas of concern beyond research misconduct were also briefly highlighted, including the quality of graduate student supervision, due diligence in hiring practices, ethics in international student recruitment, and inappropriate relationships between faculty and students. Each one of these themes has the potential to undermine institutional integrity, societal trust, and reputation.

In order to further strengthen Canadian higher education's culture of integrity, our first recommendation is that a comprehensive study of misconduct by Canadian academics and administrators be undertaken. As previously suggested, the categories identified by Stone and Starkey (2011) could provide a useful starting point for developing a survey of questionable behaviours and identifying suggested strategies for combatting them, as well as emerging systemic issues that may be catalyzing such behaviours. Data from such a study could be invaluable in informing policy and practice.

As Eaton (2021) pointed out, universities need effective policies and procedures to address scholarly and scientific misconduct among faculty, staff, and researchers. Moreover, such policies need to have a clear directive to address such misconduct in a clear and timely manner. Just as institutions produce annual reports regarding student academic misconduct, so too should they be transparent in their reporting of employee academic misconduct. The time has passed for dismissing misconduct among professors and other employees of the academy as "one off" incidents each time they occur. As we have shown, it is undeniable that faculty misconduct occurs in Canada, with some individuals engaging in numerous incidents over many years. Misconduct should not be ignored or trivialized, but instead addressed in ways that focus on accountability, transparency and prevention.

With respect to efforts to advance a national culture of research integrity, it has been several years since Canada's HAL (2009) and CCA (2010) comprehensive studies were commissioned and new oversight bodies and policies created. Perhaps it is time to revisit the original findings and recommendations, and where changes have been made, assess their effectiveness. While we appreciate the PRCR's commitment to engaging in a review every five years, including a process of public consultation, the proposed revisions for 2021 appear to be largely technical in nature. What we are proposing would be a more conceptual review, exploring the extent to which the original deficits have been resolved, such as the observation that Canada has lagged its Western counterparts in dealing with scientific misconduct. Most important, would be an assessment of the extent to which stated goals have been achieved, including the acknowledged need to "foster a positive, values-based environment of research integrity in Canada" (CCA, 2010, p. 2).

In closing, we offer this chapter as a reminder that academic integrity needs to be understood as pertaining to much more than student misconduct. We call for academic integrity to be valued as a broad-based institutional priority, involving all members. Only by having role models of integrity — faculty and administrators who bring the highest standards to their own work and deal with violations appropriatelywill Canadian higher educational institutions have the moral authority to lead their students in their own academic journeys, and to earn the trust of the public, in the scholarly work we pursue. 


\section{References}

21st Annual Edelman Trust Barometer. (2021). https://www.edelman.com/trust/2021-trust-bar ometer

Alphonso, C. (2017, June 20). Former TDSB director guilty of plagiarizing his $\mathrm{PhD}$, panel says. The Globe and Mail. https://www.theglobeandmail.com/news/toronto/former-tdsb-director-gui lty-of-plagiarizing-his-phd-panel-says/article35403977/

Besvinick, S. L. (1983). Integrity and the future of the university. Journal of Higher Education, 51(5), 566-573.

Bill 151 (2017). Bill 151, An Act to prevent and fight sexual violence in higher education institutions. National Assembly of Quebec. http://www.assnat.qc.ca/en/travaux-parlementaires/projetsloi/projet-loi-151-41-1.html

Brennan, R. J. (2012, September 12). Waterloo prof and student caught up in plagiarism scandal. The Star. https://www.thestar.com/news/canada/2012/09/12/waterloo_prof_and_ student_caught_up_in_plagiarism_scandal.html

Bretag, T. (Ed.). (2016). Handbook of academic integrity. Springer.

Broitman, M. (2016). Corruption in higher ed: Canada in the crosshairs. Inside Higher Ed.https:// www.insidehighered.com/blogs/world-view/corruption-higher-ed-canada-crosshairs

CBC News. (2011, June 12). U of Alberta dean stole speech: Med students. https://www.cbc.ca/ news/canada/edmonton/u-of-alberta-dean-stole-speech-med-students-1.1047550

CBC News. (2012, December 10). University of Windsor suspends education dean over plagiarism. CBC News Windsor. http://www.cbc.ca/news/canada/windsor/university-of-windsor-suspendseducation-dean-over-plagiarism-1.1256511

CBC News. (2005). The secret life of Dr. Chandra. https://www.youtube.com/watch?v=2R7-QM8 eKCM

CBC News. (2019, July 4). 22 electricians penalized after probe into cheating at Sask Polytechnic. https://www.cbc.ca/news/canada/saskatchewan/construction-electricians-cer tificates-cancelled-suspended-1.5200227

CCA. (2010). Honesty, accountability and trust: Fostering research integrity in Canada, Expert Panel on Research Integrity. The Council of Canadian Academies. https://cca-reports.ca/reports/ honesty-accountability-and-trust-fostering-research-integrity-in-canada/

Chen, D. (2012, May 30). Dean of education at University of Windsor suspended over plagiarism. Windsor Star. http://windsorstar.com/news/local-news/dean-of-education-at-university-ofwindsor-suspended-over-plagiarism

Colleges and Institutes Canada. (2021). https://www.collegesinstitutes.ca/stratplan/

CTV News. (2013, January 8). Internal probe finds UW prof guilty of plagiarism. https://kitchener. ctvnews.ca/internal-probe-finds-uw-prof-guilty-of-plagiarism-1.1105263

Christensen Hughes, J (2022). Academic integrity across time and place: Higher education's questionable moral calling. In S. E. Eaton \& J. Christensen Hughes (Eds.), Academic integrity in Canada: An enduring and essential challenge. Springer.

Christensen Hughes, J., \& Eaton, S. E. (2022). Student integrity violations in the academy: More than a decade of growing complexity and concern. In S. E. Eaton \& J. Christensen Hughes (Eds.), Academic integrity in Canada: An enduring and essential challenge. Springer.

Consent to Disclosure of Personal Information-Frequently Asked Questions. (2016). Natural Sciences and Engineering Research Council of Canada. Retrieved May 28, 2021, from https://www.nserc-crsng.gc.ca/NSERC-CRSNG/governance-gouvernance/consen tFAQ-consentementFAQ_eng.asp

Dalton, R. (2005, March 23). Obesity expert owns up to million-dollar crime. Nature, 434-424. https://doi.org/10.1038/434424a

Dea, S. (2019, January 18). The price of academic freedom.University Affairs. https://www.univer sityaffairs.ca/opinion/dispatches-academic-freedom/the-price-of-academic-freedom/

Dixon, B. (1989). Growing catalogue of fraud. BMJ: British Medical Journal, 299(6711), 13291330. https://www.jstor.org/stable/29706127 
Eastman, J., Jones G., Bégin-Caouette, O., Li, S., Noumi, C., \& Trottier, C. (2018). Autonomy in Canada: Findings of a comparative study of Canadian university governance. Canadian Journal of Higher Education, 48(3), 65-81. https://journals.sfu.ca/cjhe/index.php/cjhe/article/view/188 $165 / 186275$

Eaton, S. E. (2021). Plagiarism in higher education: Tackling tough topics in academic integrity. Libraries Unlimited.

Eaton, S. E. (2020a, January 13). An inquiry into major academic integrity violations in Canada: 2010-2019. http://hdl.handle.net/1880/111483

Eaton, S. E. (2020b). Significant incidents of academic misconduct in Canada 2010-2019_Timeline Infographic. http://hdl.handle.net/1880/111435

Feith, J. (2020, July 5). Human Rights Commission says Concordia University should change how it deals with sexual assault complaints. Montreal Gazette. https://montrealgazette.com/news/ local-news/human-rights-commission-says-concordia-university-should-change-how-it-dealswith-sexual-assault-complaints

Funk, C., Hefferon, M., Kennedy, B., \& Johnson, C. (2019, August 2). Trust and mistrust in Americans' views of scientific experts. https://www.pewresearch.org/science/2019/08/02/trust-and-mis trust-in-americans-views-of-scientific-experts/

Gervais. (2021). Practical methodological reform needs good theory, perspectives on psychological science. Sage. https://doi.org/10.1177/1745691620977471

HAL. (2009). The state of research integrity and misconduct policies in Canada. Canadian Research Integrity Committee. HAL Innovation Policy Economics. https://www.nserc-crsng.gc.ca/_doc/ NSERC-CRSNG/HAL_Report_e.pdf

Hamilton, D. G., Fraser, H., Hoekstra, R., Fidler, F. (2020, November 19). Meta-research: Journal policies and editors' opinions on peer review. eLife. https://elifesciences.org/articles/62529

Hendry, L. (2019, April 4), Students, staff left in the dark after Concordia's investigation of prof's behaviour. CBCNews. https://www.cbc.ca/news/canada/montreal/students-staff-left-in-the-darkafter-concordia-s-investigation-of-prof-s-behaviour-1.5081527

Hoag, H. (2010, October 21). Canada urged to tackle research misconduct. Nature. https://www. nature.com/news/2010/101021/full/news.2010.555.html

Huistra, P., \& Paul, H. (2021). Systemic explanations of scientific misconduct: Provoked by spectacular cases of norm violation? Journal of Academic Ethics. https://doi.org/10.1007/s10805-02009389-8

Humber College. (n.d.). Academic Integrity Policies \& Resources. https://healthsciences.humber. $\mathrm{ca} /$ current-students/academic-integrity.html

ICAI. (2021). The fundamental values of academic integrity (3rd ed.). International Center for Academic Integrity. https://academicintegrity.org/images/pdfs/20019_ICAI-FundamentalValues_R12.pdf

It Takes All of Us. (2021). Concordia University. https://www.concordia.ca/conduct/sexual-vio lence/training.html

Jaschik, S. (2018). Falling confidence in higher ed: Gallup finds unusually large drop—primarily but not exclusively among republicans_-between 2015 and 2018. Inside Higher Ed. https://www. insidehighered.com/news/2018/10/09/gallup-survey-finds-falling-confidence-higher-education

Jerema, C. (2010, March 15). NSERC bars scientist from receiving grants. Maclean's. https://www. macleans.ca/education/uniandcollege/nserc-bars-scientis-from-receiving-grants/

Jones, C. (2021, January 30). The coming publication apocalypse. The Grumpy Geophysicist. https:// grumpygeophysicist.wordpress.com/2021/01/30/the-coming-publication-apocalypse/

Kondro, W., \& Hebert, P. (2007). Research misconduct? What misconduct? Canadian Medical Association Journal, 176(7), 905.

Komnenic, A. (2016, December 14). In Canada, case spurs concern over misconduct secrecy. Science. https://www.sciencemag.org/news/2016/12/canada-case-spurs-concern-overmisconduct-secrecy

Laidlaw, S. (2009, August 22). Canadian named in HRT scandal. The Toronto Star. https://www. thestar.com/life/health_wellness/2009/08/22/canadian_named_in_hrt_scandal.html 
Leo, G. (2014, November 13). University of Regina prof investigated for allegedly plagiarizing student's work. $C B C$ News. https://www.cbc.ca/news/canada/saskatchewan/university-of-reginaprof-investigated-for-allegedly-plagiarizing-student-s-work-1.2832907

Mandel, M. (2019, February 26). Disgraced former TDSB chief loses bid to reclaim PhD. Toronto Sun. https://torontosun.com/news/local-news/mandel-disgraced-former-tdsb-chief-chris-spenceloses-bid-to-reclaim-phd

Maracle, I. B. J. (2020). Seven grandfathers in academic integrity. Student Life, University of Toronto. https://uwaterloo.ca/academic-integrity/sites/ca.academic-integrity/files/uploads/ files/slc8581_7-grandfathers-in-academic-integrity-aoda.pdf

Merriam Webster. (n.d. a). Integrity. https://www.merriam-webster.com/dictionary/integrity

Merriam Webster. (n.d. b). Misconduct. https://www.merriam-webster.com/dictionary/misconduct Mullens, A. (2000, December). Cheating to Win, University Affairs (pp. 22-28).

Munro, M. (2010, March 13). U of C Prof Hit by funding scandal. Calgary Herald. https://www. pressreader.com/canada/calgary-herald/20100313/296009146948158

Munro, M. (2011, September 19). Scientist fudges grant forms with fake research, studies. Regina-Leader Post. https://www.pressreader.com/canada/regina-leader-post/20110919/282376 921308922

Munro, M. (2013, December 2). China's academic 'black market' fooled Canadian journal, report says. https://margaretmunro.wordpress.com/2013/12/02/chinas-academic-black-market-fooledcanadian-journal-report-says/\#more-953

Munro, M. (2014, September 4). Prolific University of Calgary doctor heads to B.C. after his team caught faking data. Post Media News. https://margaretmunro.wordpress.com/2014/09/04/prolificuniversity-of-calgary-doctor-heads-to-b-c-after-his-team-caught-faking-data/\#more-1198

Oransky, I. (2016, July 19). Canada funding agency bans researcher for fraud, and in first, reveals her name. Retraction Watch. https://retractionwatch.com/2016/07/19/canada-funding-agency-bansresearcher-for-fraud-and-in-first-reveals-her-name/

Oransky, I., \& Markus, A. (2010, August 3). Why write a blog about retractions? Retraction Watch. https://retractionwatch.com/2010/08/03/why-write-a-blog-about-retractions/

Osipian, A. (2004). Corruption as a legacy of the medieval university: Financial affairs, MPRA Paper 8472. University Library of Munich. https://mpra.ub.uni-muenchen.de/8472/1/MPRA_p aper_8472.pdf

Osipian, A. (2007). Higher education corruption in world media, prevalence, patterns and forms. In Proceedings of 32nd Annual Conference of the Association for the Study of Higher Education (ASHE), Louisville, Kentucky, MPRA Paper 8475. University Library of Munich. https://mpra. ub.uni-muenchen.de/8475/

Policy 60, Ryerson University. (n.d.). Academic Integrity. Retrieved May 27, 2021, from https:// www.ryerson.ca/senate/course-outline-policies/academic-integrity-policy-60/

Postmedia News. (2012, September 11). Top Canadian scientist and award-winning student caught in 'blatant plagiarism' of text. National Post. https://nationalpost.com/news/canada/university-ofwaterloo-researchers-issue-retraction-and-apology-after-using-u-s-experts-text-and-information

PRCR. (2016). Mandate: Terms of reference. Panel on Responsible Conduct of Research. https:// rcr.ethics.gc.ca/eng/about_us-propos_de_nous.html

PRCR. (2017). Disclosures. Panel on Responsible Conduct of Research. https://rcr.ethics.gc.ca/eng/ disclosures-divulgations_backgrounder-document.html

RCR Framework. (2016). Tri-Agency Framework: Responsible Conduct of Research. (2016). Panel on Responsible Conduct of Research. Retrieved May 28, 2021, from https://rcr.ethics.gc.ca/eng/ framework-cadre.html

RCR Framework - Proposed Revisions for Public Consultation. (2016/2021). Consultation. Panel on Responsible Conduct of Research. https://rcr.ethics.gc.ca/eng/consultations_proposed-revisi ons-to-rcr-framework-2016.html

Retraction Watch. (n.d. a). Retraction Watch. https://retractionwatch.com/

Retraction Watch. (n.d. b). Retracted coronavirus (COVID-19) papers. Retraction Watch. https:// retractionwatch.com/retracted-coronavirus-covid-19-papers/ 
Retraction Watch. (n.d. c). Retraction watch database user guide. Retraction Watch. https://retrac tionwatch.com/retraction-watch-database-user-guide/

Retraction Watch. (n.d. d). Retraction watch database user guide appendix B: Reasons. https://ret ractionwatch.com/retraction-watch-database-user-guide/retraction-watch-database-user-guideappendix-b-reasons/

Retraction Watch. (2017). A new record: Major publisher retracting more than 100 studies from cancer journal over fake peer reviews. Retraction Watch. https://retractionwatch.com/2017/04/ 20/new-record-major-publisher-retracting-100-studies-cancer-journal-fake-peer-reviews/

Retraction Watch. (2020a). Journal retracts 70-year-old article on homosexuality for "long discredited beliefs, prejudices, and practices". Retraction Watch. https://retractionwatch.com/2020/ 12/02/journal-retracts-70-year-old-article-on-homosexuality-for-long-discredited-beliefs-prejud ices-and-practices/

Retraction Watch. (2020b). Psychology journal retracts two articles for being "unethical, scientifically flawed, and based on racist ideas and agenda". Retraction Watch. https://retractionwatch. com/2020/12/29/psychology-journal-retracts-two-articles-for-being-unethical-scientifically-fla wed-and-based-on-racist-ideas-and-agenda/

Robinson. (2016, July 12). Canadian researchers who commit scientific fraud are protected by privacy laws. Toronto Star. https://www.thestar.com/news/canada/2016/07/12/canadian-resear chers-who-commit-scientific-fraud-are-protected-by-privacy-laws.html

Smith, R. (2006). Research misconduct: The poisoning of the well. Journal of the Royal Society of Medicine, 99(5), 232-237. https://www.ncbi.nlm.nih.gov/pmc/articles/PMC1457763/

Statistics Canada. (2018/2019). Number and salaries of full-time teaching staff at Canadian universities (final), 2018/2019. https://www150.statcan.gc.ca/n1/daily-quotidien/191125/dq191125beng.htm

Stone, M., \& Starkey, M. (2011). The possible impact of university corruption on customers' ethical standards. Journal of Database Marketing \& Customer Strategy Management, 18, 154-170. https://doi.org/10.1057/dbm.2011.18

University of Waterloo. (n.d.). What is academic integrity? https://uwaterloo.ca/academic-integr ity/what-academic-integrity-0

Weaver, M. (2000, October 19). Baby died after doctor ignored mother's pleas. https://www.telegr aph.co.uk/news/health/1370882/Baby-died-after-doctor-ignored-mothers-pleas.html

Julia Christensen Hughes, Ph.D. has long advocated for ensuring the highest standards of academic integrity in higher education. Her article, Academic Misconduct within Higher Education in Canada, with the late Don McCabe (published in 2006, in the Canadian Journal of Higher Education), received the Sheffield Award for research excellence (2007), from the Canadian Society for Studies in Higher Education. As former and founding Dean of the Gordon S. Lang School of Business and Economics (2009-2019) at the University of Guelph, Julia was a champion of business ethics, corporate social responsibility and the need for business schools to be aligned with the UN's Sustainable Development Goals (SDG's). In her new role as President of Yorkville University, Julia is looking forward to supporting the institution's long-standing commitment to integrity, that is at the core of its values.

Sarah Elaine Eaton, Ph.D. is an Associate Professor in the Werklund School of Education and the inaugural Educational Leader in Residence, Academic Integrity, University of Calgary. She is also the Editor-in-Chief of the International Journal for Educational Integrity and the author of Plagiarism in Higher Education: Tackling Tough Topics in Academic Integrity (ABC Clio, 2021). Her research focuses on ethics and integrity in higher education and she has led numerous research teams and the local and national levels. Eaton advocates for pro-active and multi-stakeholder approaches to upholding and enacting integrity throughout the academy. 
Open Access This chapter is licensed under the terms of the Creative Commons Attribution 4.0 International License (http://creativecommons.org/licenses/by/4.0/), which permits use, sharing, adaptation, distribution and reproduction in any medium or format, as long as you give appropriate credit to the original author(s) and the source, provide a link to the Creative Commons license and indicate if changes were made.

The images or other third party material in this chapter are included in the chapter's Creative Commons license, unless indicated otherwise in a credit line to the material. If material is not included in the chapter's Creative Commons license and your intended use is not permitted by statutory regulation or exceeds the permitted use, you will need to obtain permission directly from the copyright holder.

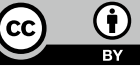

